\title{
PENGARUH STRATEGI PEMBELAJARAN ONLINE TERHADAP CAPAIAN HASILBELAJAR SISWA KELAS III SD NEGERI 122358 PEMATANGSIANTAR
}

\author{
Osco Parmonangan Sijabat ${ }^{1}$, Tarida Simanjuntak ${ }_{4}^{2}$, Apriani Sijabat ${ }^{3}$, \\ Srinatalia Silaen . \\ 1,2 Universitas HKBP Nommensen, 3,4 Universitas HKBP Nommensen \\ Pematangsiantar
}

Email: oscosijabat@uhn.ac.id ${ }^{1}$, ridajuntak@yahoo.com² ${ }^{2}$, aprianisijabat@gmail.com³, srinatalia.silaen92@gmail.com

\begin{abstract}
This study aims to describe online learning during the Covid19 pandemic as a learning strategy and learning outcomes for third grade students at SD Negeri 122358 Pematangsiantar. The problem to be answered from this research is: How can online learning strategies during the Covid19 pandemic affect the learning achievement of third grade students at SD Negeri 122358 Pematangsiantar? This study uses a qualitative method, the informants of this research are the principal, third grade teacher, and 2 third grade students of SD Negeri 122358 Pematangsiantar. The data collection of this research was done through interviews, observation, and documentation. The data analysis technique used is data reduction, data compilation and categorization. The results of this study indicate that online learning is carried out online by planning and implementing, the planning is to make materials and evaluation questions, while the implementation is to distribute materials and assignments to WhatsApp groups and students who do not have cellphones take questions to school or the teacher comes to students' homes. . Student learning outcomes show that not all students can undergo online learning and not all student learning outcomes are achieved due to various factors such as students not having cellphones or WhatsApp applications, internet signals that are difficult to reach because students' homes are in the village, students' awareness of their responsibilities in doing work. assignments are still lacking, and parental awareness and environmental conditions are less supportive so that student learning outcomes are less than optimal.
\end{abstract}

Keywords: Online Learning, Learning Strategies, Learning Outcomes.

\section{ABSTRAK}

Penelitian ini bertujuan untuk mendeskripsikan pembelajaran online pada masa pandemi Covid19 sebagai strategi pembelajaran dan capaian hasil belajar pada siswa kelas III SD Negeri 122358 Pematangsiantar. Masalah yang ingin dijawab dari penelitian ini adalah: Bagaimanakah strategi pembelajaran online pada masa pandemi Covid19 dapat mempengaruhi capaian belajar siswa kelas III SD Negeri 122358 Pematangsiantar? Penelitian ini menggunakan metode kualitatif, informan penelitian ini adalah kepala sekolah, guru kelas III, dan 2 orang siswa kelas III SD Negeri 122358 Pematangsiantar. Pengumpulan data penelitian ini dilakukan melalui wawancara, observasi, dan dokumentasi. Teknik analisis data yang digunakan dengan reduksi data, penyusunan data dan kategorisasi. Hasil penelitian ini menunjukkan bahwa pembelajaran online dilaksanakan secara daring dengan menyusun perencanaan dan pelaksanaan, perencanaannya yaitu membuat materi dan soal evaluasi, sedangkan pelaksanaannya yaitu membagikan materi dan tugas ke grup WhatsApp serta siswa yang tidak memiliki handphone mengambil soal ke sekolah atau guru datang ke rumah siswa. Hasil belajar siswa menunjukkan bahwa tidak semua siswa dapat menjalani pembelajaran online dan hasil belajar siswa tidak semua tercapai disebabkan berbagai faktor seperti siswa tidak mempunyai handphone atau aplikasi WhatsApp, signal internet yang sulit dijangkau sebab rumah siswa yang berada di desa, kesadaran siswa akan tanggungjawabnya dalam mengerjakan tugas masih kurang, dan kesadaran orangtua maupun kondisi lingkungan yang kurang mendukung sehingga capaian hasil belajar siswa kurang maksimal.

Kata Kunci: Pembelajaran Online, Strategi Pembelajaran, Hasil Belajar. 


\section{PENDAHULUAN}

Pandemi Covid19 telah merubah tatanan kehidupan masyarakat, tidak hanya menyerang negara Indonesia namun juga melanda dunia. Keberadaan Covid19 membuat masyarakat untuk memberhentikan aktivitas di luar rumah yang semestinya dilakukan seperti pada hari-hari biasa. Masyarakat harus menjaga jarak aman atau disebut dengan physical distancing, keadaan di mana orang-orang dikarantina dan diisolasi di dalam rumah masing-masing termasuk dalam melaksanakan pekerjaan sehingga setiap individu yang rentan tidak akan tertular virus Covid19. Apabila masyarakat ingin keluar rumah untuk memenuhi kebutuhan pokok seperti membeli sesuatu untuk kebutuhan sehari-hari masyarakat diwajibkan menggunakan masker dan tentu dengan menjaga jarak aman dengan orang lain. Pelaksanaan karantina dan isolasi mandiri yang dihimbau oleh pemerintah tentu tidak hanya berimbas pada pekerjaan masyarakat saja, akan tetapi juga berdampak pada sistem pendidikan yang mesti tetap berjalan. Wabah virus Covid19 berdampak pada kegiatan belajar mengajar siswa dan guru. Kegiatan yang mana biasa dilaksanakan di dalam ruang kelas pada lingkungan sekolah kini berubah menjadi dengan belajar di dalam rumah. Kondisi ini tentu tidak mudah dilalui oleh masyarakat, di mana orang tua ikut berperan sebagai guru atau pengajar ketika belajar di dalam rumah. Siswa diberikan tugas sebagai sarana untuk mengetahui pencapaian atau penilaian kemampuan siswa. Adapun kecemasan pada diri siswa di mana tugas yang diberikan oleh guru sebagai kegiatan memindahkan aktivitas kelas dari belajar di sekolah menjadi belajar di rumah dibebankan pada siswa bahkan lebih banyak. Selain itu, sekolah tetap melakukan kegiatan penilaian untuk kepentingan rapor kenaikan kelas pada tiap-tiap kelas. Kegiatan belajar dari rumah yang diterapkan oleh masyarakat menyebabkan siswa dan guru kehilangan kesempatan untuk berinteraksi satu sama lain dalam menjalin hubungan sosial, menumbuhkan sikap solidaritas antar sesama manusia, kehilangan rasa peduli dan empati. Kegiatan yang seharusnya siswa dan guru lalui memberikan pembelajaran tidak hanya tentang materi pelajaran namun juga menyampaikan tentang pentingnya bersosialisasi dalam kehidupan bermasyarakat. Keadaan ini belum bisa dilaksanakan karena adanya himbauan physical distancing dari pemerintah guna melakukan pencegahan terhadap penyebaran virus Covid19.

Belajar dari rumah tentu berbeda dengan kegiatan belajar di sekolah, selain adanya perangkat pembelajaran kegiatan belajar juga didukung oleh media belajar untuk memudahkan siswa dalam memahami materi. Menurut Indriana (2011: 15) media pembelajaran dimaksudkan merupakan salah satu alat komunikasi dalam proses pembelajaran, dikatakan demikian karena di dalam proses pembelajaran terdapat proses penyampaian pesan dari pendidik kepada anak didik. Media pembelajaran juga diartikan sebagai salah satu faktor eksternal yang berpengaruh terhadap keberhasilan kegiatan pembelajaran, secara umum manfaat media pembelajaran yakni untuk memperlancar interaksi anatar guru dengan siswa sehingga pembelajaran lebih efektif dan efisien (Numiek, 2013: 94-95).

Terdapat beberapa hal dalam mempertimbangkan memilih media pembelajaran yang tepat, menentukan ketepatan dalam memilih media akan mempengaruhi efektivitas dan efisiensi proses pembelajaran. Media yang digunakan belum tentu merupakan media yang mahal dan modern, namun sebaliknya jenis media yang harganya murah dan sederhana yang mudah dibuat serta mudah didapatkan mungkin lebih efektif dan efisien (Zainul, 2017:10). Salah satu cara dalam 
mengatasi pembelajaran siswa dan guru di sekolah dengan mengubah sistem pembelajaran di rumah yakni menggunakan sistem pembelajaran online atau daring. Pembelajaran online dilakukan menggunakan gadget masing-masing baik berupa smartphone, laptop, komputer, atau tablet. Penggunaan pembelajaran online dirasa merupakan strategi yang tepat dalam menggantikan pembelajaran di kelas. Perubahan strategi belajar tentu dilengkapi dengan media belajar yang baru, sebagai penunjang dalam kegiatan pembelajaran. Pada kondisi ini pergantian sistem pembelajaran biasa menjadi pembelajaran online diikuti pula dengan media belajar lain yaitu media internet. Penerapan pembelajaran online dapat berjalan dengan lancar dan stabil bila dibantu oleh adanya koneksi jaringan internet yang akan diakses pada perangkat gadget. Media pembelajaran mempunyai fungsi sebagai sumber belajar dan dapat sebagai sarana perantara dalam penyampaian informasi, maka dari itu media pembelajaran memiliki peran penting dalam penggunaan sistem pembelajaran online pada masa pandemi Covid19.

Jadi, pembelajaran online yang diterapkan pada masa pandemi Covid19 merupakan strategi baru yang diterapkan untuk melanjutkan kegiatan belajar mengajar antara pendidik dan siswa yang dapat dilaksanakan dari rumah, kegiatan tersebut tidak lepas dari penggunaan media internet agar dapat efektif dalam penerapannya. Pada pelaksanaannya siswa dan guru tidak perlu lagi melakukan kegiatan belajar mengajar secara tatap muka di ruang kelas, namun kini sudah bisa belajar dengan sistem pembelajaran online. Guru memberi tugas harian sebagai sarana pemerolehan nilai siswa yang akan dicantumkan dalam rapor. Penilaian tersebut sebagai acuan tercapainya tujuan pembelajaran sesuai dengan apa yang diharapkan di tengah wabah virus Covid19. Guru juga dapat menggunakan strategi pembelajaran dengan Google Classroom sebagai suatu serambi aplikasi pembelajaran campuran secara online yang dapat digunakan secara gratis. Pendidik bisa membuat kelas mereka sendiri dan membagikan kode kelas tersebut atau mengundang para siswanya. Google Classroom ini diperuntukkan untuk membantu semua ruang lingkup pendidikan yang membantu siswa untuk menemukan atau mengatasi kesulitan pembelajaran, membagikan pelajaran dan membuat tugas tanpa harus hadir ke kelas. Google Classroom merupakan aplikasi berbasis E-learning, penyampaianpembelajaran dengan e-learning merupakan pembelajaran dengan memanfaatkan teknologi internet untuk meningkatkan lingkungan belajar dengan konten yang kaya dengan cakupan yang luas. E-learning merupakan pemanfaatan media pembelajaran menggunakan internet, untuk mengirimkan serangkaian solusi yang dapat meningkatkan pengetahuan dan keterampilan. Setiap metode pembelajaran harus mengandung rumusan pengorganisasian bahan pelajaran, strategi penyampaian, dan pengelolaan kegiatan dengan memperhatikan faktor tujuan belajar, hambatan belajar, karakteristik peserta didik, agar dapat diperoleh efektivitas, efisiensi, dan daya tarik pembelajaran (Miarso, 2004).

Melalui pembelajaran online siswa siswa dapat menggali informasi dan matei pembelajaran sesuai dengan silabus yang telah ditetapkan oleh guru. Pembelajaran online membuat siswa memiliki informasi yang tak terbatas karena mereka dapat mengakses informasi dari berbagai sumber yang sesuai dengan materi pembelajarannya. Kegiatan yang dapat siswa lakukan pada pembelajaran online bisa berupa diskusi online dengan yang ahli pada bidangnya, dapat pula melalui e-mail atau chatting. Diterapkannya sistem pembelajaran online diharapkan dapat mencapai hasil akhir pada proses belajar dengan baik, dapat memenhi ketuntasan belajar, dan tetap menjalankan kagiatan pendidikan ditengah pandemi. Bahan pembelajaran online yang 
dirancang guru menentukan hasil belajar dari siswa, bahan yang dirancang dengan baik dan profesional akan menunjang kegiatan bekajar siswa dengan efisien. Penyusunan bahan ajar oleh guru juga harus memperhatikan dan penggunaan alat multimedia. Bahan belajar dapat berupa teks, gambar, grafik, animasi, simulasi, audio, dan video. Pemilihan warna yang tepat pada bahan belajar akan mempengaruhi efektifitas pembelajaran yang ditampilkan pada layar monitor.

Hal ini dapat menjadikan pembelajaran online sebuah model belajar yang menarik, berkesan bagi siswa, interaktif, dan atraktif. Hal ini sejalan dengan penelitian yang dilakukan oleh Edi Santoso (2009) tentang "Pengaruh Pembelajaran Online Terhadap Presentasi Belajar Kimia Ditinjau dari Kemampuan Awal Siswa: Studi Pada Siswa SMA Negeri 1 Purwantoro, Wonogiri, menunjukkan bahwa pembelajaran online memberikan pengaruh yang lebih tinggi daripada pembelajaran dengan menggunakan LKS terhadap prestasi belajar kimia. Terdapat perbedaan pengaruh yang signifikan antara jenjang kemampuan awal tinggi dengan jenjang kemampuan awal rendah terhadap prestasi belajar kimia siswa, tidak ada interaksi pengaruh yang signifikan antara jenis penggunaan media dengan jenjang kemampuan awal siswa terhadap prestasi belajar kimia siswa, serta pembelajaran online dapat digunakan untuk meningkatkan prestasi belajar siswa. Dari uraian diatas, peneliti menarik masalah yang akan dikaji dalam penelitian ini adalah terkait strategi pembelajaran online pada masa pandemi Covid19 dan pengaruhnya terhadap capaian hasil belajar kelas III SD Negeri 122358 Pematangsiantar Tahun Ajaran 2020/2021.

\section{METODE PENELITIAN}

Jenis Penelitian ini adalah penelitian deskriptif, dalam pelaksanaannya menggunakan pendekatan kualitatif. Penelitian deskripsi merupakan suatu penelitian paling dasar, yang bertujuan untuk mendeskripsikan suatu fenomena yang terjadi, baik fenomena yang bersifat alami maupun fenomena buatan manusia. Penelitian deskriptif yakni sebuah tindakan yang mempelajari mengenai bentuk, aktivitas, karakter, hubungan, perubahan, perbedaan, dan kesamaan dengan suatu fenomena lainnya. Hasil yang diperoleh dari tindakan penelitian ini dapat menemukan temuantemuan yang penting sebagai contoh sebuah temuan mengenai sistem tata surya, tanaman yang tumbuh, kehidupan seseorang terhadap lingkungannya, dan sebagainya. Berdasarkan penjabaran dari data kualitatif, tujuan yang hendak dicapai oleh peneliti adalah untuk memperoleh penjelasan mengenai cara seseorang menjelaskan suatu hal yang dilakukan tentang aktivitas, rancangan, menguraikan suatu situasi yang terdiri dari suatu peristiwa untuk menjelaskan tindakan tertentu yang tidak dapat dipisahkan dari keadaan lingkungan yang tersedia, dan mendeskripsikan dan menjelaskan proses berlangsungnya suatu tindakan itu dapat terjadi dan cara tindakan tersebut dilakukan. Penelitian ini dilakukan di SD Negeri 122358 Pematangsiantar yang merupakan pertama kalinya melakukan penerapan pembelajaran online pada tahun 2020 ini.

Penelitian dilakukan di luar jam aktif pelajaran, di mana guru memberikan atau mengirimkan tugas melalui WhatsApp, aplikasi Google Classroom, atau media aplikasi lainnya. Data yang dihimpun terdiri dari macam-macam data tentang pembelajaran online pada masa pandemi Covid19 sebagai strategi pembelajaran dan capaian hasil belajar pada siswa kelas III SD Negeri 122358 Pematangsiantar. Data yang dikumpulkan pada umumnya meliputi data primer dan data sekunder. Data primer merupakan suatu data yang disusun oleh peneliti yang digunakan untuk mencapai tujuan dalam menyelesaikan permasalahan yang akan diteliti. Peneliti 
mengumpulkan data-data langsung yang diperoleh dari sumber utama atau tempat penelitian tersebut dilaksanakan.

Adapun data yang diperoleh merupakan hasil dari wawancara dengan kepala sekolah, guru kelas III, dan siswa kelas III yangberjumlah 2 anak, terdiri dari 1 siswa laki-laki dan 1 siswa perempuan. Pada penelitian ini, dokumentasi didapatkan melalui instrumen-instrumen wawancara. Instrumen wawancara tersebut dapat berupa buku catatan, tape recorder atau perekam suara, dan kamera. Buku catatan digunakan untuk mencatat hasil wawancara dengan narasumber agar tidak lupa atau bahkan hilang. Perekam suara juga berfungsi untuk merekam pernyataan-pernyataan darikoresponden secara detail dan dapat diputar berulang-ulang untuk dapat mengingatnya. Sedangkan kamera berguna untuk mengabadikan kegiatan wawancara dengan koresponden tersebut sebagai bukti dokumentasi bahwa telah melakukan wawancara.

Analisis data pada penelitian kualitatif merupakan teknik yang diarahkan untuk menjawab rumusan masalah atau menguji hipotesis yang telah dirumuskan. Berikut ini merupakan tahap-tahap dalam analisis data, antara lain: reduksi data, penyusunan satuan, dan kategorisasi . Agar penelitian memperoleh keabsahan data, maka peneliti menggunakan teknik triangulasi, teknik ini merupakan sebuah pemeriksaan atau pengecekan keabsahan data dengan menggunakan berbagai sumber yang dilakukan dengan cara yang beragam. validator dalam pengecekan keabsahan data yang disusun oleh peneliti yaitu Kepala Sekolah dan satu guru kelas III SD Negeri 122358 Pematangsiantar.

\section{HASIL DAN PEMBAHASAN PENELITIAN}

1. Hasil Observasi Pembelajaran online pada masa pandemi covid19 sebagai strategi pembelajaran dan capaian hasil belajar siswa kelas III SD Negeri 122358 Pematangsiantar.

Pada masa pandemi Covid19 sekolah menerapkan pembelajaran online atau daring di rumah untuk mencegah penyebaran virus corona. Pembelajaran yang dijalankan setelah datangnya pandemi sangat berbeda tidak seperti sebelum pandemi, siswa dapat belajar di sekoah dan guru dapat menyampaikan langsung materi pelajaran kepada siswa. Untuk itu sekolah merubah sistem pembelajaran tatap muka di kelas menjadi pembelajaran online yang dilaksanakan dari rumah. Berikut pernyataan narasumber yang merupakan wali kelas III SD Negeri 122358 Pematangsiantar: "Pembelajaran yang diterapkan saat pandemi adalah dengan cara berkomunikasi lewat WhatsApp, guru memberikan materi atau tugas melalui pesan WhatsApp berupa teks, video, atau link. Bagi siswa yang tida punya handphone atau WhatsApp guru datang ke rumah siswa memberikan soal atau bahan ajar sesuai kebutuhan." (Observasi secara daring melalui WhatsApp 26 Juni 2020 jam 15.36).

\section{Laporan Hasil Wawancara Pembelajaran online pada masa pandemi covid19 sebagai strategi pembelajaran dan capaian hasil belajar siswa kelas III SD Negeri 122358 Pematangsiantar.}

Wawancara dilaksanakan secara bertahap, dalam penelitian ini penulis melibatkan 4 orang narasumber, diantaranya yaitu Kepala Sekolah, guru kelas III, dan 2 orang siswa kelas III yang dipilih secara acak oleh guru kelas III. Terkait dengan pembelajaran online yang dilaksanakan pada masa pandemi Covid 19 yang diterapkan di kelas III SD Negeri 122358 Pematangsiantar menjelaskan:"Pembelajaran online merupakan sebuah tantangan bagi guru, karena 
guru harus mengatur ulang strategi pembelajaran agar materi pembelajaran dapat tersampaikan kepada siswa, guru juga membuat media pembelajaran yangbaru seperti membuat video, menyusun soal-soal, dan melakukan penilaian lainnya." (Wawancara, Roni, 28 Juni 2020).

"Untuk pembelajaran online kami membuat strategi baru, yaitu membuat grup WhatsApp untuk mengirimkan tugas kepada siswa. Setiap hari guru akan memantau dengan mengirimkan sebuah link yang nantinya siswa akan mengumpulkan tugas-tugasnya. Ketika pembelajaran online aktivitas yang dilakukan guru adalah mengirimkan materi baik itu berupa foto, video, atau buku LKS kemudian mengirimkannya kepada siswa." (Wawancara, Roni, 28 Juni 2020)

"Pembelajaran online dilakukan dengan menggunakan aplikasi WhatsApp, untuk ulangan harian dengan menggunakan Google form, cara-cara tersebut digunakan untuk yang tercapai daring. Apabila ada yng tidak tercapai daring maka guru akan mendatangi rumah siswa untuk memberikan tugas satu minggu sekali. Persentase yang menggunakan daring hanya $75 \%$ karena dariada beberapa faktor yang mempengaruhi terhambatnya daring. Jadi, ada siswa yang memakai daring/online dan ada siswa yang menggunakan luring (luar jaringan) untuk siswa yang tidak dapat mengakses aplikasi." (Wawancara, Tuti, 29 Juni 2020).

Terkait dengan perencanaan dan pelaksanaan yang terdapat pada pembelajaran online, dibuktikan dengan hasil wawancara berikut ini: "Ada perencanaan dan pelaksanaan pembelajarannya. Perencanaannyaya membuat materi dan soal evaluasi, pelaksanaannya ya ngeshare ke Group WA dan menyuruh siswa yang tidak punya WA mengambil soal ke sekolah atau terkadang guru yang ke rumah siswa. Selain itu guru juga membuat RPP untuk pembelajaran online”. (Wawancara, Roni, 28 Juni 2020). Penjelasan tentang strategi pembelajaran yang diterapkan dalam pembelajaran online di masa pandemi Covid 19 pada kelas III sebagai berikut: "Strategi pembelajarannya dengan membuat grup WhatsApp dan link Google form untuk mengirimkan tugas kepada siswa, guru memberikan materi atau tugas lewat grup WhatsApp, dikirim melalui link Google form, guru membuat soal- soal yang ringan agar siswa tidak terbebani." (Wawancara, Roni, 28 Juni 2020) "Guru membuat strategi pembelajaran dengan mengumpulkan materi belajar yang menarik, agar siswa tidak bosan. Latihan soal-soalnya juga dikemas lebih menarik seperti kuis. Selain itu, guru juga memberi reward bagi anak yang rajin mengerjakan tugas.

Berikut terkait tentang pendekatan dan metode yang digunakan guru dalam mengatur strategi pembelajaran online, antara lain: "Pendekatan yang dilaksanakan yaitu menerangkan materi melalui video, kemudian untuk siswa yang offline atau luring yaitu siswa mempelajari materi di LKS. Kemudian metodenya yaitu menggunakan video pembelajaran, jadi guru membuat video sedang menerangkan materi." (Wawancara, Roni, 28 Juni 2020). Penjelasan tentang alokasi waktu kegiatan daring dan luring serta pengumpulan tugasnya, yaitu: "Alokasi waktunya berbeda dari pembelajaran normal, kalau daring dilakukan setiap hari, kalau offline alokasi waktunya mandiri dan waktu pengumpulan tugasnya itu sesuai dengan kesepakatan dari guru misalnya seminggu sekali tugasnya dikumpulkan". (Wawancara, Roni, 28 Juni 2020). Berkaitan dengan kelebihan dan kelemahan strategi pembelajaran yang dipakai ketika pembelajaran online, sebagai berikut: "Kelemahannya siswa merasa bosan, selalu berkeinginan untuk belajar di sekolah. Ada juga orang tua yang sibuk bekerja sehingga kurang maksimal dalam memantau anak-anaknya belajar, ada siswa yang tidak punya smartphone ataupun tidakn punya aplikasi WhatsApp sehingga siswa sulit mendapatkan materi dan tugas dari guru, signal yang susah karena 
letaknya yang di desa. Kelebihannya perkembanan siswa dapat dipantau langsung oleh orang tua dan mengetahui kekurangan yang belum dicapai siswa, dalam hal teknologi baik siswa ataupun orang tua menjadi bisa menjalankan smartphone, memperoleh pengetahuan untuk menjalankan WhatsApp yang dapat digunakan untuk mengerjakan tugas dengan cepat." (Wawancara, Roni, 28 Juni 2020).

Penjelasan tentang faktor pendukung dan penghambat kegiatan pembelajaran online sebagai berikut: "Faktor pendukungnya yaitu ada anggaran untuk guru, guru diberikan fasilitas oleh madrasah seperti kuota internet sebagai penunjang berjalannya pemberian tugas kepada siswa, dan pembuatan link Google form disediakan oleh sekolah. Sedangkan faktor penghambatnya adalah signal yang sulit terjangkau karena letak siswa yang berada di desa, tidak semua siswa dapat menjangkau signal untuk mengakses WhatsApp dan Google form, kemudian siswa merasa jenuh dan respon siswa terhadap siswa masih kurang." (Wawancara, Roni. 28 Juni 2020).

Penjelasan tentang media yang digunakan dalam pembelajaran online yakni sebagai berikut: "Guru menggunakan media dengan jaringan internet, guru menggunakan video untuk menerangkan materi, membuat soal-soal, lalu kuis lewat internet, kemudian guru juga memberikan reward untuk siswa yang rajin dan tepat waktu dalam mengirimkan tugas." (Wawancara, Roni, 28 Juni 2020). Penjelasan tentang rata-rata ketercapaian siswa kelas III dalam pembelajaran online sebagai berikut: "Pembelajaran daring tidak harus tercapai semua, karena mengingat kondisi pengguna daring dari madrasah hanya $75 \%$, itu artinya tidak semua siswa menggunakan daring, ada sebagian siswa yang mengerjakan tugas offline dengan cara mendatangi rumah siswa satu persatu. Hal ini disebabkan oleh faktor siswa yang tidak punya handphone maupun aplikasi WhatsApp dan sulit menjangkau signal." (Wawancara, Roni, 28 Juni 2020).

"Karena pembelajaran online itu sebenarnya tidak efektif maka ketercapaian siswa tidak bisa tercapai secara maksimal, hal ini disebabkan oleh tidak adanya target untuk mencapai KI dan KD. Seperti yang disampaikan oleh Menteri Pendidikan Pak Nadim Makarim bahwa pada masa pandemi ini guru tidak terbebani untuk mengejar target KI dan KD. Pada umunya seharusnya ada target untuk mengejar KI dan KD untuk ketercapaian siswa. Akan tetapi jika pada pembelajaran online diberikan target sesuai KI dan KD maka tidak sesuai, siswa akan terlalu terbebani oleh tugas-tugas yang sangat banyak. Untuk itu selama daring tidak diterapkan target KI dan KD karena hal itu hanya akan membebani siswa dengan banyak tugas, sedangkan di masa sulit ini siswa tidak boleh terbebani banyak tugas." (Wawancara, Herman, 29 Juni 2020).

"Karena guru tidak bisa bertemu langsung, kesimpulannya adalah jika siswa itu sudah mengerjakan tugas, nilainya sudah bagus, sudah menyimakmateri dari grup WhatsApp maka saya anggap sudah paham jika tidak ada siswa yang bertanya, dan guru tidak bisa mengukur atau mengetes sejauh mana siswa paham dengan materi yang dibagikan, yang terpenting adalah materi pelajaran sudah tersampaikan ke siswa." (Wawancara, Roni, 28 Juni 2020).

Penjelasan tentang rata-rata ketercapaian siswa kelas III B dari pelaksanaan pembelajaran online, sebagai berikut: "Jumlah siswanya ada 17, 13 anak menggunakan daring, 4 anak menggunakan luring" (Wawancara, Roni, 28 Juni 2020). Penjelasan mengenai hasil belajar siswa kelas III SD Negeri 122358 Pematangsiantar dalam pembelajaran online pada masa pandemi Covid19, sebagai berikut: "Hasil belajar untuk kelas III mengalami penurunan dalam segi materinya, karena materi yang tersampaikan tidak semuanya terserap siswa. Selain itu, hasil belajar juga 
mengalami peningkatan dalam segi keterampilan mereka, seperti sikap mereka di rumah, kemudian mereka mengeksplorasi pengetahuan di rumah meskipun di luar materi dalam pembelajaran, tetapi di rumah siswa mungkin dapat belajar lebih luas dan memperdalam bakat mereka.” (Wawancara, Roni, 28 Juni 2020).

Berdasarkan hasil observasi dan wawancara tentang pembelajaran online pada masa pandemi Covid19 menjelaskan bahwa di kelas III guru telah menerapkan pembelajaran online atau daring dalam kegiatan belajar dari rumah sebagai wujud pencegahan penyebaran virus corona dibuktikan dari hasil observasi sebagai berikut: "Pembelajaran online dilakukan dengan menggunakan aplikasi WhatsApp, untuk ulangan harian dengan menggunakan Google form, cara- cara tersebut digunakan untuk yang tercapai daring. Apabila ada yng tidak tercapai daring maka guru akan mendatangi rumah siswa untuk memberikan tugas satu minggu sekali. Persentase yang menggunakan daring hanya $75 \%$ karena dari ada beberapa faktor yang mempengaruhi terhambatnya daring. Jadi, ada siswa yang memakai daring/online dan ada siswa yang menggunakan luring (luar jaringan) untuk siswa yang tidak dapat mengakses aplikasi." (Wawancara, Herman, 29 Juni 2020).

Pernyataan di atas menjelaskan bahwa pembelajaran online dilaksanakan dengan menggunakan aplikasi WhatsApp dalam menyampaikan materi kepada siswa, tugas-tugas harian juga dikirim melalui WhatsApp. Pernyataan tersebut didukung oleh hasil wawancara pada tanggal 29 Juni 2020. Ulangan harian dikerjakan siswa melalui Google form, ketika siswa sudah selesai mengerjakan tugas maka hasilnya bisa langsung sampai pada guru. Namun tidak semua siswa dapat belajar menggunakan daring, persentase siswa yang memakai daring hanya $75 \%$ karena ada beberapa faktor penghambat siswa dalam mengakses materi dan tugas. Siswa yang tidak dapat menjalani daring maka tetap belajar dengan luring (luar jaringan). Hal tersebut juga didukung oleh pernyataan mengenai pembelajaran online yang dilakukan menggunakan aplikasi WhatsApp, sebagai berikut: "Pembelajaran yang diterapkan saat pandemi adalah dengan cara berkomunikasi lewat WhatsApp, guru memberikan materi atau tugas melalui pesan WhatsApp berupa teks, video, atau link. Bagi siswa yang tida punya handphone atau WhatsApp guru datang ke rumah siswa memberikan soal; atau bahan ajar sesuai kebutuhan." (Observasi secara daring melalui WhatsApp 26 Juni 2020 jam 15.36)

Berdasarkan pernyataan di atas menunjukkan bahwa pembelajaran online telah digunakan pada siswa kelas III dalam kegiatan belajar mengajardi masa pandemi Covid19. Pernyataan ini didukung dengan data observasi yang dilakukan pada tanggal 26 Juni 2020 jam 15.36 secara daring melalui WhatsApp. Pembelaajran online ini diterapkan agar kegiatan belajar tetap berjalan walaupun harus di rumah saja. Pembelajaran online dilaksanakan dengan cara berkomunikasi melalui aplikasi WhatsApp, guru mengirimkan materi pelajaran dan mengirimkan tugas-tugas kepada siswa melalui WhatsApp yang dapat berupa teks, video, atau link Google form guna mengirimkan tugas pembiasaan siswa yang merupakan program unggulan sekolah. Guru membuat perencanaan dan pelaksanaan dalam pembelajaran online, terkait dengan perencanaan dan pelaksanaannya dibuktikan dengan hasil wawancara berikut ini: "Ada perencanaan dan pelaksanaan pembelajarannya. Perencanaannya ya membuat materi dan soal evaluasi, pelaksanaannya ya ngeshare ke Group WA dan menyuruh siswa yang tidak punya WA mengambilsoal ke sekolah atau terkadang guru yang ke rumah siswa. Selain itu guru juga membuat RPP untuk pembelajaran online". (Wawancara, Roni, 28 Juni 2020). Pernyataan di atas menjelaskan bahwa dalam pembelajaran online guru mempersiapkan perencanaan dan pelaksanaan kegiatan. 
Perencanaan yangdilakukan yaitu guru membuat materi dan soal evaluasi, sedangkan pelaksanaannya yaitu guru membagikan materi dan tugas ke grup WhatsApp kemudian siswa yang tidak mempunyai WhatsApp diminta oleh guru datang ke sekolah untuk mengambil soal atau tugas, selain siswa yang diminta datangke sekolah terkadang guru yang mendatangi rumah siswa. Terdapat beberapa faktor pendorong dan penghambat strategi pembelajaran dibuktikan dengan hasil wawancara berikut: "Faktor pendukungnya yaitu ada anggaran untuk guru, guru diberikan fasilitas oleh sekolahh seperti kuota internet sebagai penunjang berjalannya pemberian tugas kepada siswa, dan pembuatan link Google form disediakan oleh sekolah. Sedangkan faktor penghambatnya adalah signal yang sulit terjangkau karena letak siswa yang berada di desa, tidak semua siswa dapat menjangkau signal untuk mengakses WhatsApp dan Google form, kemudian siswa merasa jenuh dan respon siswa terhadap tugas masih kurang." (Wawancara, Roni. 28 Juni 2020).

Berdasarkan pernyataan tersebut, menjelaskan bahwa terdapat beberapa faktor pendorong dan penghambat pelaksanaan pembelajaran online. Pernyataan ini didukung dengan data wawancara yang dilakukan pada tanggal 28 Juni 2020. Faktor pendorongnya yaitu sekolah menyediakan anggaran kepada guru untuk membelikan kuota internet yang digunakan untuk membuat akun Google form maupun membuat grup akun WhatsApp guna mengirimkan materi dan tugas kepada siswa. Faktor penghambatnya yaitu jaringan internet atau signal yang sulit dijangkau oleh siswa karena rumah siswa yang berada di desa, tidak semua daerah mudah menjangkau signal internet. Kendala lainnya berasal dari diri siswa sendiri yang memiliki kesadaran yang kurang terhadap tugas-tugas yang harus siswa kerjakan.

Sistem pembelajaran yang berubah berpengaruh juga terhadap strategi yang digunakan dalam mengajar. Berbeda dari strategi sebelumnya yang menggunakan metode-metode seperti metode diskusi, metode ceramah, maupun metode penugasan lainnya pada masa pandemi Covid19 guru juga mengubah strategi pembelajaran tersebut. Hal ini bertujuan untuk menyampaikan materi atau informasi kepada siswa agar siswa dapat mencapai suatu target penilaian tertentu. Berdasarkan hasil observasi dan wawancara tentang strategi pembelajaran pada masa pandemi Covid19 menjelaskan bahwa menurut observasi guru membuat strategi pembelajaran yang berbeda dari startegi yangdipakai saat sebelum pandemi, berikut bukti hasil observasi strategi pembelajaran: "Guru membuat strategi pembelajaran dengan mengumpulkan materi belajar yang menarik, agar siswa tidak bosan. Latihan soal-soalnya juga dikemas lebih menarik seperti kuis. Selain itu, guru juga memberi reward bagi anak yang rajin mengerjakan tugas. (Observasi secara daring melalui WhatsApp 26 Juni 2020 jam 15.36).

Berdasarkan pernyataan di atas, menunjukkan bahwa strategi guru dalam pembelajaran online yakni dengan membuat materi belajar yang menarik agar siswa tidak bosan belajar di rumah. Pernyataan ini didukung dengan data observasi yang dilakukan pada tanggal 26 Juni 2020 jam 15.36 secara daring. Pembelajaran yang monoton dan biasa saja dapat membuat siswa jenuh ketika harus belajar di rumah, untuk itu guru membuat strategi belajar yang berbeda dengan mengirimkan materi berupa foto maupun video yang menarik, membuat kuis soal lalu kemudian siswa mengirimkan tugasnya ke link Google form. Pelaksanaan pembelajaran online juga mengharuskan guru untuk membuat strategi pembelajaran yang baru, berikut bukti hasil wawancara tentang pembelajaran online yang mendorong guru untuk membuat strategi pembelajaran baru: "Untuk pembelajaran online kami membuat strategi baru, yaitu membuat grup WhatsApp untuk mengirimkan tugas kepada siswa. Setiap hari 
guru akan memantau dengan mengirimkan sebuah link yang nantinya siswa akan mengumpulkan tugas-tugasnya. Ketika pembelajaran online aktivitas yang dilakukan guru adalah mengirimkan materi baik itu berupa foto, video, atau buku LKS kemudian mengirimkannya kepada siswa." (Wawancara, Roni,28 Juni 2020).

Berdasarkan pernyataan di atas menunjukkan bahwa pembelajaran online menyebabkan guru membuat strategi pembelajaran baru. Pernyataan ini didukung dengan data wawanvara pada tanggal 18 Juni 2020. Strategi yang digunakan setelah pandemi datang berbeda dengan sebelum adanya pandemi, sebelum pandemi datang pembelajaran dilakukan di sekolah dengan pertemuan tatap muka kemudian menggunakan strategi pembelajaran yang sesuai di dalam kelas. Pada saat pandemi guru merubah strategi pembelajaran ketika menyampaikan materi dan memberikan tugas melalui aplikasi WhatsApp, guru memberikan materi baik berupa teks, foto, maupun video. Dalam pelaksanaan strategi pembelajaran, guru menyusun pendekatan dan metode yang digunakan guru dalam mengatur strategi pembelajaran online, hal ini dibuktikan dengan hasil wawancara berikut: "Pendekatan yang dilaksanakan yaitu menerangkan materi melalui video, kemudian untuk siswa yang offline atau luring yaitu siswa mempelajari materi di LKS. Kemudian metodenya yaitu menggunakan video pembelajaran, jadi guru membuat video sedang menerangkan materi." (Wawancara, Roni, 28 Juni 2020).

Berdasarkan penjelasan di atas dapat diketahui bahwa pendekatan dan metode belajar disusun untuk dapat menerapkan strategi pembelajaran. Pendekatan yang dilakukan adalah guru menerangkan materi melalui video, siswa yang menjalani offline mempelajari materi dari LKS (lembar kerja siswa). Sedangkan metodenya adalah guru menggunakan video sebagai alat pembelajarannya, guru merancang sebuah video yang di dalamnya terdapat guru yang sedang menerangkan materi pelajaran dengan direkam kemudian dibagikan melalui grup WhatsApp. Pelaksanaan startegi pembelajaran terdapat alokasi waktu kegiatan daring dan luring, serta metode dalam pengumpulan tugas siswa dibahas dalam wawancara berikut ini: "Alokasi waktunya berbeda dari pembelajaran normal, kalau daring dilakukan setiap hari, kalau offline alokasi waktunya mandiri dan waktupengumpulan tugasnya itu sesuai dengan kesepakatan dari guru misalnya seminggu sekali tugasnya dikumpulkan". (Wawancara, Roni, 28 Juni 2020).

Berdasarkan pernyataan dari wawancara di atas, dapat diketahui bahwa alokasi waktu yang dilaksanakan ketika pembelajaran online berbeda dengan pembelajaran biasa ketika di sekolah. Pada pembelajaran online dilakukan setiap hari, sedangkan offline atau luring alokasi waktunya secara mandiri atau ditentukan sendiri. Sistem pengumpulan tugasnya sesuai dengan kesepakatan yang sudah ditetapkan oleh guru. Strategi pembelajaran baru dapat memberikan manfaat bagi guru untuk menambah pengetahuan dan meningkatkan kemampuan dalam penggunaan teknologi. Namun ada strategi pembelajaran yang diterapkan pada masa pandemi Covid19 ini mempunyai kelebihan dan kelemahan, hal tersebut dibuktikan dengan pernyataan sebagai berikut: "Kelemahannya siswa merasa bosan, selalu berkeinginan untuk belajar di sekolah. Ada juga orang tua yang sibuk bekerja sehingga kurang maksimal dalam memantau anak-anaknya belajar, ada siswa yang tidak punya smartphone ataupun tidakn punya aplikasi WhatsApp sehingga siswa sulit mendapatkan materi dan tugas dari guru, signal yang susah karena letaknya yang di desa. Kelebihannya perkembanan siswa dapat dipantau langsung oleh orang tua dan mengetahui kekurangan yang belum dicapai siswa, dalam hal teknologi baik siswa ataupun orang tua menjadi bisa menjalankan smartphone, memperoleh pengetahuan 
untuk menjalankan WhatsApp yang dapat digunakan untuk mengerjakan tugas dengan cepat." (Wawancara, Roni, 28 Juni 2020)

Pernyataan tersebut menjelaskan bahwa strategi pembelajaran baru memiliki kelemahan dan kelebihan. Pernyataan ini didukung dengan data hasilwawancara pada tanggal 28 Juni 2020. Kelemahannya adalah siswa merasa bosan bila belajar di rumah, orang tua siswa yang sibuk bekerja sehingga kurang dapat memantau belajar anak. Jaringan internet terkadang tidak dapat dijangkau atau susah signal karena leta rumah siswa yang di desa, ada siswa yang di rumah tidak punya handphone atau smartphone yang ada aplikasi WhatsApp nya sehingga siswa tidak dapat mengakses materi dan tugas yang diberikan guru. Sedangkan kelebihan dari strategi pembelajaran ini adalah siswa dapat dipantau langsung oleh orang tua sehingga orang tua dapat mengetahui sampai sejauh mana anak mereka paham tentang materi pelajaran dan mengetahui kekurangan belajar yang ada pada diri siswa. Kelebihan lainnya dalam hal teknologi baik untuk orang tua maupun siswa itu sendiri dapat menambah pengetahuan dan kemampuan menggunakan teknologi, seperti orang tua dan siswa dapat menjalankan internet untuk mengakses materi dan tugas, dan menggunakan aplikasi WhatsApp untuk pendidikan. Pada pembelajaran online, strategi pembelajaran didukung dengan penggunaan media belajar. Guru juga menggunakan media belajar untuk memudahkan siswa memahami materi yang disampaikan secara daring. Pernyataan ini dibuktikan dari hasil wawancara berikut: "Guru menggunakan media dengan jaringan internet, guru menggunakan video untuk menerangkan materi, membuat soal-soal, lalu kuis lewat internet, kemudian guru juga memberikan reward untuk siswa yang rajin dan tepat waktu dalam mengirimkan tugas." (Wawancara, Roni, 28 Juni 2020).

Berdasarkan pernyataan wawancara tersebut, guru menggunakan media belajar lewat internet untuk menyampaikan materi kepada siswa berupa video, guru membuat soal-soal kuis yang kemudian diunggah di Google form agar siswa tidak mudah jenuh dengan tugas yang biasa-biasa saja. Kemudian guru memberikan reward pada siswa yang rajin mengerjakan tugas dan mengirimkan tugas tepat waktu. Hasil belajar siswa diperoleh setelah mengikuti kegiatan pembelajaran. Berdasarkan hasil wawancara tentang hasil belajar siswa kelas III pada masa pandemi Covid19 menjelaskan bahwa hasil belajar siswa tidak harus tercapai semua, pernyataan ini dibuktikan dari hasil wawancara sebagai berikut: "Pembelajaran daring tidak harus tercapai semua, karena mengingat kondisi pengguna daring dari madrasah hanya $75 \%$, itu artinya tidak semua siswa menggunakan daring, ada sebagian siswa yang mengerjakan tugas offline dengan cara mendatangi rumah siswa satu persatu. Hal ini disebabkanoleh faktor siswa yang tidak punya handphone maupun aplikasi WhatsApp dan sulit menjangkau signal.” (Wawancara, Roni, 28 Juni 2020).

Berdasarkan pernyataan di atas, hasil pembelajaran daring tidak harus semuanya tercapai, karena banyak kendala yang menghambat proses kegiatan daring seperti ketidaktersedianya fasilitas untuk daring seperti smartphone, tidak ada aplikasi WhatsApp, dan signal yang sulit dijangkua. Pernyataan ini didukung dengan data wawancara tanggal 28 Juni 2020. Tidak semua siswa menggunakan daring, persentase siswa yang melaksanakan daring hanya $75 \%$. Ada beberapa siswa yang melaksanakan offline dikarenakan kendala-kendala tersebut. Siswa yang melaksanakan offline dengan cara guru mendatangi rumah siswa satu persatu untuk memberikan materi dan tugas. Guru datang setiap satu minggu sekali, dan tugas yang diberikan juga berlaku untuk satu minggu. Hasil yang diperoleh dari pembelajaran online tidak maksimal karena pembelajaran secara daring dinilai kurang efektif untuk sistem pembelajaran pada siswa kelas III. 
Hal ini dibuktikan dari pernyataan hasil wawancara berikut: "Karena pembelajaran online itu sebenarnya tidak efektif maka ketercapaian siswa tidak bisa tercapai secara maksimal, hal ini disebabkan oleh tidak adanya target untuk mencapai KI dan KD. Seperti yang disampaikan oleh Menteri Pendidikan Pak Nadim Makarim bahwa pada masapandemi ini guru tidak terbebani untuk mengejar target KI dan KD. Pada umunya seharusnya ada target untuk mengejar KI dan KD untuk ketercapaian siswa. Akan tetapi jika pada pembelajaran online diberikan target sesuai KI dan KD maka tidak sesuai, siswa akan terlalu terbebani oleh tugas-tugas yang sangat banyak. Untuk itu selama daring tidak diterapkan target KI dan KD karena hal itu hanya akan membebani siswa dengan banyak tugas, sedangkan di masa sulit ini siswa tidak boleh terbebani banyak tugas." (Wawancara, Herman, 29 Juni 2020)

Berdasarkan pernyataan di atas, menjelaskan bahwa pelaksanaan pembelajaran online yang diterapkan sesungguhnya tidak efektif karena tidak bisa mencapai KI dan KD secara maksimal. Pernyataan tersebut didukung dengan data wawancara tanggal 29 Juni 2020. Pembelajaran yang tidak berpedoman pada KI dan KD akan tidak menghasilkan target belajar sesuai KI dan KD. Hal tersebut telah disampaikan juga Menteri Pendidikan Indonesia Nadim Makarim tentang tidak adanya target KI dan KD dala pembelajaran daring. Pada pembelajaran umum ada target KI dan KD untuk menunjang hasil belajar siswa, namun dengan adanya pandemi Covid19 yang mengharuskan siswa belajar dari rumah maka pembelajaran online tidak dibebani target KI dan KD. Pembelajaran daring menyebabkan guru dan siswa tidak bisa bertatap muka secara langsung sehingga tidak dapat mengetahui secara langsung apakah siswa memahami materi dengan benar atau belum. Hal ini dibuktikan dengan hasil wawancara sebagai berikut: "Karena guru tidak bisa bertemu langsung, kesimpulannya adalah jika siswa itu sudah mengerjakan tugas, nilainya sudah bagus, sudah menyimak materi dari grup WhatsApp maka saya anggap sudah paham jika tidak ada siswa yang bertanya, dan guru tidak bisa mengukur atau mengetes sejauh mana siswa paham dengan materi yang dibagikan, yang terpenting adalah materi pelajaran sudah tersampaikan ke siswa." (Wawancara, Roni, 28 Juni 2020)

Pernyataan tersebut didukung dengan data wawancara pada tanggal 28 Juni 2020 menjelaskan bahwa pemahaman siswa tidak dapat diukur secara langsung oleh guru karena tidak dapat memantau siswa secara langsung. Pemahaman siswa dapat diketahui berdasarkan nilai mereka, apabila menunjukkan hasil yang baik maka siswa dianggap telah memahami materi. Hal penting dari guru yakni siswa telah menerima materi pelajaran. Berikut merupakan pernyataan tentang rata-rata ketercapaian siswa kelas III B dalam pembelajaran online, didukung oleh hasil dari wawancara berikut: "Jumlah siswanya ada 17, 13 anak menggunakan daring, 4 anak menggunakan luring" (Wawancara, Roni, 28 Juni 2020). Berdasarkan pernyataan di atas menjelaskan bahwa ketercapaian siswa kelas III pengguna daring dari jumlah siswa satu kelas 17 anak, terdapat 13 siswa yang mengikuti pembelajaran online dan 4 siswa menjalani pembelajaran offline atau luring. Berikut hasil wawancara mengenai hasil belajar siswa kelas III dalam pembelajaran online pada masa pandemi Covid19. Hasil belajar menunjukkan beberapa kenaikan dan penurunan, dibuktikan dari hasil wawancara sebagai berikut: "Hasil belajar untuk kelas III mengalami penurunan dalam segi materinya, karena materi yang tersampaikan tidak semuanya terserap siswa. Selain itu, hasil belajar juga mengalami peningkatan dalam segi keterampilan mereka, seperti sikap mereka di rumah, kemudian mereka mengeksplorasi pengetahuan di rumah meskipun di luar materi dalam pembelajaran, tetapi di rumah siswa mungkin dapat belajar lebih luas dan memperdalam bakat mereka." (Wawancara, Roni, 28 Juni 2020). 
Berdasarkan pernyataan di atas yang didukung dengan data wawancara tanggal 18 Juni 2020 menjelaskan bahwa dari kegiatan pembelajaran online hasil belajar siswa kelas III SD Negeri 122358 Pematangsiantar mengalami penurunan sekaligus mengalami kenaikan. Siswa mengalami penurunan dalam segi materi, materi pelajaran yang tersampaikan tidak semua dapat diserap oleh siswa. Selain mengalami penurunan, siswa juga mengalami kenaikan hasil belajar dari segi keterampilan. Siswa dapat mengasah keterampilan mereka selama belajar dari rumah dan memperkaya pengetahuan. Pembelajaran online di SD Negeri 122358 Pematangsiantar menggunakan aplikasi internet sebagai media dalam menyampaikan materi dan pemberian tugas dalam pembelajaran. Media tersebut yakni menggunakan aplikasi WhatsApp dengan memanfaatkan fitur WhatsApp Group, guru menggunakan bantuan video dalam menerangkan materi agar siswa lebih mudah memahami yang kemudian dikirim di dalam WhatsApp Group tersebut. Selain itu guru juga menggunakan Google form dalam menerima tugas- tugas dari siswa. Aplikasi ini lebih efisien dalam menampung tugas siswa karena tidak memakan memori dalam gawai milik guru maupun sekolah, karena tersimpan otomatis di laman internet tersebut. Jadi, dalam pembelajaran online guru hanya menggunakan fitur aplikasi WhatsApp Group dan Google Form untuk mengirim materi dan tugas kepada siswa. Penggunaan video dalam pembelajaran online guru membuatnya kemudian dikirim melalui WhatsApp Group. Guru merekam kegiatan sedang menerangkan materi kemudian mengaploadnya di group tersebut. Cara ini bertujuan untuk memudahkan siswa menangkap dan memahami materi dari pembelajaran jarak jauh ini.

Penggunaan Google Form dimanfaatkan guru untuk melaksanakan ulangan harian atau penilaian lainnya. Penerapan ini berguna bagi guru karena lebih efisien sehingga guru tidak perlu menyiapkan dalam bentuk print out yang kemudian diserahkan kepada siswa. Pada laman Google Form ini siswa bisa langsung mengisi atau memilih jawaban pada smartphone/gawai tanpa harus print out. Guru juga menggunakan Google Form untuk penilaian akhir semester. Berikut ini merupakan tabel hasil penilaian akhir semester ganjil tahun ajaran 2020/2021.

Tabel 1 Penilaian Akhir Tahun Semester Ganjil tahun ajaran 2020/2021

\begin{tabular}{|c|c|c|c|c|}
\hline No & Mata Pelajaran & $\begin{array}{c}\text { Jumlah } \\
\text { Siswa }\end{array}$ & $\begin{array}{c}\text { Capaian } \\
\text { Target }\end{array}$ & $\begin{array}{l}\text { Rata } \\
\text { Rata }\end{array}$ \\
\hline 1 & Agama & 17 & $100 \%$ & 83,53 \\
\hline 2 & PPkN & 17 & $100 \%$ & 77,65 \\
\hline 3 & Bahasa Indonesia & 17 & $100 \%$ & 77,06 \\
\hline 4 & Matematika & 17 & $100 \%$ & 75,29 \\
\hline 5 & SBdP & 17 & $100 \%$ & 78,24 \\
\hline 6 & PJOK & 17 & $100 \%$ & 82,94 \\
\hline 7 & Bahasa Daerah & 17 & $100 \%$ & 80,59 \\
\hline
\end{tabular}

Sumber: data primer diolah

Berdasarkan data di atas, dapat dijelaskan bahwa daftar nilai siswa pada semester ganjil rata-rata nilai yang tertinggi ada pada mata pelajaran Agama dengan rata-rata 83,53 dan rata-rata nilai terendah terdapat pada mata pelajaran matematika dengan angka 75,29.

Tabel 2 Penilaian Akhir Tahun Semester Genap tahun ajaran 2020/2021

\begin{tabular}{ccccc}
\hline No & Mata Pelajaran & Jumlah & Capaian & Rata \\
\hline
\end{tabular}

Volume: 4 No. 2 Juli 2021

JURNAL ILMIAH AQUINAS Terbit Juli dan Januari Setiap Tahunnya 


\begin{tabular}{ccccc}
\hline & & Siswa & Target & Rata \\
\hline 1 & Agama & 17 & $100 \%$ & 82,94 \\
\hline 2 & PPkN & 17 & $100 \%$ & 77,65 \\
\hline 3 & Bahasa Indonesia & 17 & $100 \%$ & 77,06 \\
\hline 4 & Matematika & 17 & $100 \%$ & 78,24 \\
\hline 5 & SBdP & 17 & $100 \%$ & 78,24 \\
\hline 6 & PJOK & 17 & $100 \%$ & 78,24 \\
\hline 7 & Bahasa Daerah & 17 & $100 \%$ & 79,41 \\
\hline
\end{tabular}

\section{Sumber: data primer diolah}

Berdasarkan data di atas menjelaskan bahwa nilai rata-rata di semester genap tertinggi terdapat pada mata pelajaran agama yaitu dengan hasil 82,94 sedangkan nilai rata-rata terendah ada pada mata pelajaran bahasa indonesia dengan nilai 77,06. Kedua tabel di atas dapat ditarik kesimpulan bahwa capaian rata-rata nilai siswa pada semester ganjil lebih tinggi daripada rata-rata nilai siswa di semester genap. Hal tersebut berarti rata-rata nilai hasil belajar siswa mengalami penurunan di semester genap karena adanya pandemi Covid19 lalu menerapkan pembelajaran online dengan berbagai kendala yang dialami sehingga capaian hasil belajar kurang maksimal.

\section{PENUTUP}

Berdasarkan hasil analisis data yang dilakukan oleh peneliti, maka dapat ditarik kesimpulan antara lain:

1. Pembelajaran online yang diterapkan pada kelas III SD Negeri 122358 Pematangsiantar merupakan suatu tantangan baru bagi guru dalam mengatur ulang strategi pembelajaran agar materi belajar dapat tersampaikan kepada siswa. Pembelajaran online dilaksanakan secara daring melalui jaringan internet dengan menyusun perencanaan dan pelaksanaan pembelajaran oleh guru. Perencanaan pembelajarannya yaitu dengan membuat materi dan soal evaluasi untuk siswa, sedangkan pelaksanaan pembelajarannya yaitu membagikan materi dan tugas ke grup WhatsApp serta meminta siswa yang tidak memiliki handphone atau WhatsApp untuk mengambil soal ke sekolah atau guru yang datang ke rumah siswa untuk memberikan tugas.

2. Strategi pembelajaran yang diterapkan pada siswa kelas III SD Negeri 122358 Pematangsiantar sebagai sebuah perencanaan rangkaian pembelajaran online dengan menggunakan pendekatan dan model belajar untuk mencapai tujuan pembelajaran. Pendekatan pembelajarannya dilakukan dengan menerangkan materi melalui video. Siswa yang menjalani luring atau offline mempelajari materi dari LKS (lembar kerja siswa) yang sudah dibawa oleh masing-masing siswa. Metode pembelajarannya yaitu guru membuat video yang sedang menerangkan materi kemudian dikirim kepada siswa melalui WhatsApp. Alokasi waktu daring dilakukan setiap hari, sedangkan offline ditentukan sendiri atau secara mandiri, dan pengumpulan tugasnya sesuai dengan kesepakatan dari guru. Media belajar yang digunakan yaitu foto atau video yang diakses dari WhatsApp kemudian siswa mengumpulkan tugasnya melalui link Google form. Materinya berasal dari buku paket siswa maupun LKS dan materi yang disampaikan sesuai dengan kompetensi dasar, kemudian guru membuat soal sebagai evaluasi pembelajaran.

3. Hasil belajar siswa menunjukkan bahwa tidak semua siswa dapat menjalani pembelajaran online dan hasil belajar tidak semua tercapai disebabkan berbagai 
faktor seperti siswa tidak mempunyai handphone atau aplikasi WhatsApp, signal internet yang sulit dijangkau sebab rumah siswa yang berada di desa, kesadaran siswa akan tanggungjawabnya dalam mengerjakan tugas masih kurang, dan kesadaran orangtua maupun kondisi lingkungan di sekitar siswa yang kurang mendukung sehingga menyebabkan capaian hasil belajar siswa kurang maksimal. Pelaksanaan pembelajaran online kurang efektif diterapkan oleh siswa kelas III SD Negeri 122358 Pematangsiantar karena tidak adanya capaian target sesuai KI dan KD.

\section{REFERENSI}

Abdi, Usman Rianse. 2012. Metodologi Penelitian Sosial dan Ekonomi. Bandung: Alfabeta. Abidin, Zainul. 2017. Penerapan Pemilihan Media Pembelajaran. Edcomtech Jurnal Kajian Teknologi Pendidikan.

Ahmadi. 2011. Strategi Pembelajaran Sekolah Terpadu. Jakarta: Prestasi Pustaka Publisher.

Asmara, A. P. 2015. Pengembangan Media Pembelajaran Berbasis Audio Visual Tentang Pembuatan Koloid. JURNAL ILMIAH DIDAKTIKA: Media Ilmiah Pendidikan dan Pengajaran, 15(2).

Baharun, Hasan. 2015. Penerapan Pembelajaran Active Learning Untuk Meningkatkan HasilBelajar Siswa di Madrasah. Jurnal Pendidikan Pedagogik, Vol. 1 No. 1.

Batubara, Hamdan Husein. 2020. Penggunaan Video Tutorial Untuk Mendukung Pembelajaran Daring di Masa Pandemi Virus Corona. Muallimuna Jurnal Madrasah Ibtidaiyah.

Darmansyah, S.T. M, Pd. 2010. Strategi Pembelajaran Menyenangkan Dengan Humor. Jakarta: Bumi Aksara.

David, Fred R. 2011. Strategic Management. Buku 1 Edisi 12 Jakarta.

Dina Indriana. 2011. Ragam Alat Bantu Media Pengajaran. Yogyakarta: Diva Press.

Fajar, I., Kamal, N., Faisal, D., Ds, S., \& Ds, M. 2017. Perencanaan Video Promosi Cafe Ombewok. DEKAVE: Jurnal Desain Komunikasi Visual, 5(2).

Fathurrahman, M., \& Sulistyorini. 2012. Belajar dan Pembelajaran. Yogyakarta: Teras. Hanum, Numiek Sulistyo. 2013. Keefektifan E-learning Sebagai Media Pembelajaran (Studi Evaluasi Model Pembelajaran E-learning SMK Telkom Sandhy Putra Purwokerto). Jurnal Pendidikan Vokasi, Vol. 3, Nomor 1.

Hapsari, Swita Amalia 2019. Pemanfaatan Google Classroom Sebagai Media Pembelajaran Online di Universitas Dian Nuswantoro. WACANA Jurnal Ilmiah Komunikasi.

Hartanto, Aat. 2010. Panduan Aplikasi Smartphone. Jakarta: Gramedia Pustaka Utama. Kemendikbud. 2016. Permendikbud Nomor 22 tahun 2016 Tentang Standar Proses Pendidikan dan Menengah. Jakarta: Kemendikbud.

Khotimah, Khusnul. 2016. Pengaruh Strategi Pembelajaran terhadap Hasil Belajar Ditinjau dari Aktivitas Belajar. Surakarta: Tiga Serangkai.

Labasariyani, N. L. P., \& Marlinda, N. 2014. Penggunaan Video Pembelajaran Sebagai Alat Bantu dalam Mempersiapkan Bahan Ajar Kalkulus I Untuk Mahasiswa STIMIK STIKOM Indonesia. Junal S@ CIES, 5, 1-3.

Mahmud, Syaifuddin, \& M. Idham. 2017. Strategi Belajar Mengajar. Syiah Kuala: Syiah Kuala University.

Mandagi, Mieke O., \& Nyoman Sudana Degeng. 2019. Model dan Rancangan Pembelajaran. Malang: CV Seribu Bintang.

Mardiana, Tria, \& Arif Miyat Purnanto. 2017. Google Form Sebagai Alternatif 
PembuatanLatihan Soal Evaluasi. Journal.ummgl.ac.id.

Moleong, Lexy J. 2011. Metodologi Penelitian Kualitatif Edisi Revisi. Bandung: PT. Remaja Rosdakarya.

Nadziroh, Faridatun. 2017. Analisa Efektifitas Sistem Pembelajaran Berbasis ELearning. Jurnal Ilmu Komputer dan Desain Komunikasi Visual 2.

Noor, Syamsudin. 2014. Penerapan Analisis SWOT Dalam Menentukan Strategi PemasaranDaihatsu Luxcio di Malang.

Nurdyansyah, N, \& Andiek Widodo. 2015. Inovasi Teknologi Pembelajaran. Sidoarjo: Nizamial Learning Center.

Richardo, \& Rini Intansari M. 2017. Impak Minat dan Motivasi Belajar terhadap HasilBelajar Siswa. Jurnal Pendidikan Manajemen Perkantoran Vol 2 No. 2.

Rosyid, Zaiful. 2019. Prestasi Belajar. Malang: Literasi Nusantara.

Rusman, dkk. 2011. Pembelajaran Berbasis Teknologi Informasi dan Komunikasi, Membangun Profesionalitas Guru. Jakarta: PT. Raja Grafindo.

Sahidillah, M. Wildan, \& Prarasto Miftahurrisqi. 2019. WhatsApp Sebagai Media LiterasiDigital Siswa. Journals.ums.ac.id.

Slameto. 2010. Belajar dan Faktor yang Mempengaruhi. Jakarta: Rineka Cipta. Sudjono, A. 2012. Pengantar Evaluasi Pendidikan. Jakarta: PT. Raja Grafindo Persada.

Sugandi, A. Suryati, \& C. Indah, D.R. 2017. Pengaruh Pembelajaran CTL Berbasis Enterpreneurship Terhadap Pemahaman Konsep Siswa Pada Materi Minyak Bumi. Prosiding Seminar Nasional Pendidik dan Pengembang Pendidikan Indonesia.

Sugiyono. 2015. Metode Penelitian: Kuantitatif, Kualitatif, dan R\&D. Bandung: Alfabeta.

Suryadi, E., Ginanjar, M. H., \& Priyatna, M. 2018. Penggunaan Sosial Media WhatsApp danPengaruhnya terhadap Disiplin Belajar Peserta Didik pada Mata Pelajaran Pendidikan Agama Islam. Jurnal Edukasi Islami Jurnal Pendidikan Islam, 07(1), 1-22. 